\title{
Mineral fibres: correlation between oxidising surface activity and DNA base hydroxylation
}

\author{
A Nejjari, J Fournier, H Pezerat, P Leanderson
}

\begin{abstract}
In relation to their potential genotoxic properties, the ability of inorganic particles to induce activated species of oxygen with strong oxidative properties can be studied by various methods. In this study the oxidative surface properties of 10 different natural and synthetic mineral fibres were investigated by: (1) an electron paramagnetic resonance technique in which formate was used to trap oxidative species; and (2) a high performance liquid chromatography (HPLC) based method in which deoxyguanosine was used as a trapping agent and the formation of 8-hydroxydeoxyguanosine (8 OHdG) was analysed. Ground iron-containing fibres such as crocidolite and amosite were the most reactive, whereas fibres without iron-for example, ceramic fibres, xonotlite, and Tismo L-were completely inactive. A good correlation was found when the results from the two methods were compared $(r=0 \cdot 86)$.
\end{abstract}

(British fournal of Industrial Medicine 1993;50:501-504)

Various tests can be used to evaluate the capacity of inorganic materials to generate electrophilic species able to trigger an oxidative stress in a biological medium. For inorganic dust, these tests implicate various activated species of oxygen arising from the interactions between the reducing surface sites of the dust and the molecular oxygen dissolved in aqueous medium. To these mechanisms, some authors add that of mobilisation and transport of the electron donor species (divalent iron for

Laboratoire de Réactivité de Surface et Structure, Université $P$ et $M$ Curie, CNRS, URA 1106, 4 place Jussieu, 75252 Paris Cédex 05, France

A Nejiari, J Fournier, H Pezerat

Department of Occupational Medicine, Faculty of

Health Sciences, S-58185 Linköping, Sweden

P Leanderson example) in the form of complexes implying low molecular weight biological ligands. ${ }^{1}$

Among the different activated species of oxygen, it is necessary to distinguish between those with strong electrophilic character (metal oxo species, hydroxyl radicals etc), able to attack a great variety of target molecules, and less electrophilic species (iron superoxo species, various complexes of $\mathrm{Fe}^{\mathrm{III}}$ ) only able to initiate lipid peroxidation. These two types of activated species of oxygen have been classified by Pezerat as $A^{\star}$ and $P^{\star}$ species, which represent two distinct subsets. ${ }^{2}$

The $A^{\star}$ species, strongly electrophilic, are easily characterised because of their reactions with molecules such as formate, ethanol, acetone, and dimethyl sulphoxide. This group is obviously capable of triggering lipid peroxidation. The appearance of $A^{\star}$ during the metabolism of asbestos fibres and of various dusts containing divalent iron, nickel, or copper in aqueous medium has been assumed in various studies. ${ }^{2-7}$

In our investigation, some natural and manmade mineral fibres were incubated in aqueous solutions and the formation of oxidizing $A^{\star}$ species (iron oxo species, $\mathrm{OH} \cdot$ ) was analysed with a technique based on analysis of 8-hydroxydeoxyguanosine (8 OHdG) after hydroxylation of deoxyguanosine (dG) and with an electron paramagnetic resonance (EPR) technique after formate oxidation.

In the $A^{\star}$ test, formate anions are oxidised to carboxylate radical anions, which are trapped by 5 5'-dimethyl-1-pyrroline-N-oxide (DMPO) according to the reactions: $\mathrm{A}^{\star}+\mathrm{HCO}_{2}^{-} \rightarrow \mathrm{AH}+\mathrm{CO}_{2}^{-}$and $\mathrm{CO}_{2}^{-}+\mathrm{DMPO} \rightarrow\left(\mathrm{DMPO}, \mathrm{CO}_{2}^{-}\right)$where $\mathrm{A}^{\star}$ represents the strongly electrophilic species, generally iron oxo species $\left(\mathrm{Fe}^{\mathrm{v}}=\mathrm{O}\right)$ appearing on the surface of the particles after interactions, in several steps, between divalent iron and molecular oxygen; $\mathrm{CO}_{3}^{-}$ is the carboxylate anion radical with a very short life; DMPO is a spin trap agent that reacts with $\mathrm{CO}_{2}$ to form (DMPO, $\mathrm{CO}_{2}^{-}$) adducts detected by EPR spectroscopy.

The test with the dG assumes that various intermediary reactions are involved before the formation of $8 \mathrm{OHdG},{ }^{89}$ and the mechanism of this transformation is not yet completely understood. ${ }^{10}$ 


\section{Materials and methods REAGENTS}

The DMPO was purchased from Sigma chemical Co, St Louis, USA, and dG was purchased from Serva Feinbio chemica GMBH, Heidelberg, Germany: 8 OHdG was synthesised according to the method of Kasai and Nishimura. ${ }^{11}$ The other compounds were obtained from normal commercial sources.

\section{FIBRE SAMPLES}

Table 1 lists the mineral fibres that were used. These include three amphibole samples, all distributed by the Union Internationale Contre le Cancer (UICC); one fibrous erionite sample; a potassium titanate distributed as a product of substitution for asbestos by a commercial company; two calcium silicate samples distributed as asbestos substitutes, one a very pure synthetic sample and the othercontaining very small amounts of iron and manganese-extracted from a stone pit then ground in a mill; one iron rich rock wool; one glass wool; and one ceramic fibre. In some cases, the sample was hand ground in an agate mortar just before the test.

Table 1 also shows the ideal formula and the origin of the samples. The titanate formula is not the one given by the supplier but the one calculated by us after various studies. ${ }^{5}$ The content of divalent iron found by chemical analysis is expressed as $\mathrm{FeO}$ content ( $\%$ by weight).

\section{FORMATE OXIDATION TEST}

Reaction mixtures contained $45 \mathrm{mg}$ of fibres, 50 $\mathrm{mM} \mathrm{DMPO}$ as a spin trap, and $1 \mathrm{M}$ sodium formate in $2 \mathrm{ml}$ of $0.5 \mathrm{M}$ aerated potassium phosphate buffer, $\mathrm{pH} 7 \cdot 4$. The reactor was protected from exposure to light. The suspension was stirred at $37^{\circ} \mathrm{C}$. After 25 and 60 minutes, aliquots were filtrated and transferred to a flat quartz EPR cell. Detection of radical adducts was performed by EPR spectroscopy two minutes after withdrawal of the aliquots. Spectral data of radical adducts agreed with those reported previously. ${ }^{34}$

The results are given as the mean of the (DMPO, $\mathrm{CO}_{2}^{-}$). signal after 25 and 60 minutes of incubation. Controls contained no solid particles, and were processed under the same experimental conditions. The signal intensity is given in arbitrary units used in previous work. ${ }^{34} \mathrm{~A}$ signal intensity of 1000 corresponds to a (DMPO, $\mathrm{CO}_{2}^{-}$) adduct concentration of $4 \cdot 1 \mathrm{M}$.

\section{2'-DEOXYGUANOSINE HYDROXYLATION TEST}

After grinding (two minutes) in an agate mortar the material was weighed and added to a phosphate buffer solution to obtain a stock mixture with a final concentration of $10 \mathrm{mg} / \mathrm{ml}$ (just before the incubation). Then $50 \mu \mathrm{l}$ of this mixture was added to $400 \mu \mathrm{l}$ of the phosphate buffer and $50 \mu \mathrm{l}$ (10 $\mathrm{mM}$ ) of a dG solution in $1.5 \mathrm{ml}$ Eppendorf test tubes. The reaction mixture contained $0.5 \mathrm{mg}$ fibre in each test $(1.0 \mathrm{mg} / \mathrm{ml})$ and the final buffer phosphate concentration was $0.5 \mathrm{M}, \mathrm{pH} \mathrm{7.4}$. The samples were incubated for one hour in darkness on a slow rotator.

The results are expressed as the ratio 8 OHdG $/ 10^{5} \mathrm{dG}$ in the reaction mixtures after 60 minutes of incubation. Analyses of $8 \mathrm{OHdG}$ and dG were performed with high performance liquid chromatography as previously described. ${ }^{8}$

In both tests the results are given as an average of three assays, with the corresponding confidence interval.

\section{Results}

Table 2 shows the (DMPO, $\mathrm{CO}^{-}$) . signal intensity and the amount of 8 OHdG formed after incubation of the different fibres.

In the formate oxidation test, ground amosite, crocidolite, wollastonite, and rock wool were the most reactive fibres, whereas air aged amosite and crocidolite were inactive. Anthophyllite, glass wool, ceramic fibres, erionite, Tismo L, and xonotlite,

Table 1 Divalent iron content by weight, expressed in $\% \mathrm{FeO}$, chemical formulas, and origin of the different fibres

\begin{tabular}{|c|c|c|c|}
\hline Fibre type & Content in $\mathrm{FeO}$ & Chemical formula (ideal) & Origin \\
\hline Amosite & $27 \cdot 0$ & $(\mathrm{Mg}, \mathrm{Fe})_{7} \mathrm{Si}_{8} \mathrm{O}_{22}(\mathrm{OH})_{2}$ & UICC \\
\hline Crocidolite & $19 \cdot 0$ & $\mathrm{Na}_{2} \mathrm{Fe}_{5} \mathrm{Si}_{8} \mathrm{O}_{22}(\mathrm{OH})_{2}$ & UICC \\
\hline Anthophyllite & 4.7 & $\mathrm{Mg}_{7} \mathrm{Si}_{8} \mathrm{O}_{22}(\mathrm{OH})_{2}$ & UICC \\
\hline Erionite & 0.7 & $\left(\mathrm{Ca}, \mathrm{Mg}, \mathrm{Na}_{2}, \mathrm{~K}_{2}\right) \mathrm{O} \cdot \mathrm{Al}_{2} \mathrm{O}_{3} .6 \mathrm{SiO}_{2} .6 \mathrm{H}_{2} \mathrm{O}$ & Mineralogical sample from Oregon (USA) \\
\hline Tismo L & 0 & $\mathrm{~K}_{2} \mathrm{Ti}_{8} \mathrm{O}_{17}$ & Commercial sample, Otsuka Chemicals \\
\hline Xonotlite & 0 & $\mathrm{CaSiO}_{3}$ (synthesis) & $\begin{array}{l}\text { Commercial sample (Promaxon), } \\
\text { Promat (Belgium) }\end{array}$ \\
\hline \multirow{4}{*}{$\begin{array}{l}\text { Wollastonite } \\
\text { NYAD } 1250 \\
\text { Rock wook } \\
\text { Glass wool } \\
\text { Ceramic fibre }\end{array}$} & & & Commercial sample “NYCO” (USA) \\
\hline & $\begin{array}{l}0.4 \\
8 \cdot 1\end{array}$ & $\mathrm{CaSiO}_{3}$ & $\begin{array}{l}\text { Commercial sample, "NYCO" (USA) } \\
\text { Rockwool Inc (Sweden) }\end{array}$ \\
\hline & 0.07 & & St Gobain (France) \\
\hline & 0 & Aluminosilicate & Keraline 45 (France) \\
\hline
\end{tabular}


Table 2 Mean oxidising capacity of minerals towards formate and dG: three assays were performed for each result

\begin{tabular}{|c|c|c|}
\hline Sample & $\left(\mathrm{DMPO}, \mathrm{CO}_{2}^{-}\right) \cdot$ signal intensity & $8 \mathrm{OH} d G / 10^{5} d G$ \\
\hline Amosite & 10 & $1.5(0.2)$ \\
\hline Amosite & $1450(100)$ & $79 \cdot 1(4 \cdot 3)$ \\
\hline Crocidolite & 30 & $3 \cdot 3(0.7)$ \\
\hline Crocidolite $^{\star}$ & $1250(50)$ & $71.0(5.6)$ \\
\hline Anthophyllite & $0-10$ & $1 \cdot 2(0 \cdot 1)$ \\
\hline Anthophyllite & $130(1.10)$ & $33.8(0.7)$ \\
\hline Erionite & $0-10$ & $0.8(<0.1)$ \\
\hline Erionite ${ }^{\star}$ & $0-10$ & $4.2(0.5)$ \\
\hline Rock wool` & $550(50)$ & $30.9(0.5)$ \\
\hline Wollastonite & 55 & $13.5(0 \cdot 3)$ \\
\hline Wollastonite & $1050(300)$ & $18 \cdot 8(1 \cdot 2)$ \\
\hline Ceramic fibre ${ }^{\star}$ & $0-10$ & $4 \cdot 1(0 \cdot 3)$ \\
\hline Glass wool* & $260(100)$ & $4 \cdot 3(0 \cdot 2)$ \\
\hline Tismo L & 0.10 & $1 \cdot 2(0 \cdot 1)$ \\
\hline Tismo $L^{\star}$ & $0-10$ & $2 \cdot 0(0 \cdot 3)$ \\
\hline Xonotlite & $0-10$ & $2 \cdot 1(0 \cdot 1)$ \\
\hline Xonotlite & $0-10$ & $3 \cdot 3(0.4)$ \\
\hline Control & $0-10$ & $0.6(<0.1)$ \\
\hline
\end{tabular}

*Ground for two minutes.

Confidence interval in parentheses.

were all inactive or poorly active.

With the dG hydroxylation method ground amosite and ground crocidolite caused the most hydroxylation (unground fibres caused very little hydroxylation). Anthophyllite, rock wool, and wollastonite formed an intermediate group and a third group glass wool, erionite, Tismo L, xonotlite, and ceramic fibres, were inactive.

\section{Discussion}

Figure 1 shows the comparison between the results of the two tests of oxidising capacity. Ten samples were studied, and there was a significant correlation between these two methods $(r=0 \cdot 86)$.

In the case of some materials-for example crocidolite, amosite, or wollastonite-grinding favours

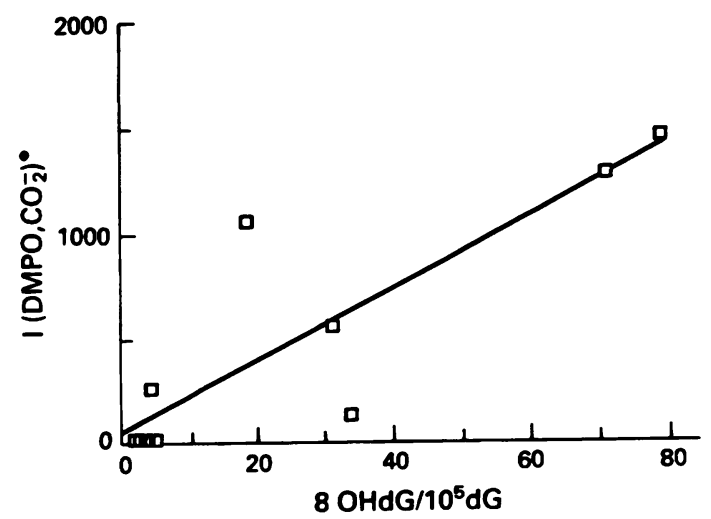

Figure 1 (DMPO,CO $) \cdot$ signal intensity $v$ ratio of the $8 \mathrm{OHdG} / 10^{5} d G$ for the 10 samples after grinding (with $\left.I\left(\mathrm{DMPOCO}_{2}^{-}\right)=46.947+16.9478 \mathrm{OHdG} / 10^{5} d G\right)$. the capacity of these materials to generate electrophilic species. We have checked that grinding for a short time allows only a small increase in the surface area (20\% for example for amosite) without an important increase in oxidising activity. So the effect of grinding is to unmask fresh non-oxidised surface, then to allow the appearance on the surface of divalent iron capable of reacting with molecular oxygen.

The agreement between the two tests was least satisfactory for wollastonite. When the results for this material were omitted, the correlation factor increased from 0.86 to $0 \cdot 95$. Moreover the oxidative activity obtained in the two tests correlated with the divalent iron content of the materials as shown in Fig 2 (where the wollastonite results have been excluded).

A second compound, anthophyllite, also gave a poor agreement between the two methods. For anthophyllite and wollastonite it is possible that the weak correlation between their oxidative capacity in the two tests is due to the difference between the ratio $W / V$ in the two methods (W is the weight of the sample and $\mathrm{V}$ the volume of medium). This ratio is much higher in the test with formate than in the test with guanosine and the relation between the oxidising capacity and the ratio $\mathrm{W} / \mathrm{V}$ probably varies with the nature of the mineral. A second factor is related to an abnormal decrease in the lifetime of the (DMPO, $\mathrm{CO}_{2}^{-}$) adducts in the presence of anthophyllite. This contributes to the weakness of formate oxidation with this mineral. The lifetime of this adduct is generally one hour, ${ }^{3}$ but with anthophyllite it is clearly reduced, as the intensities of the signals were 800,240 , and 20 at 10,25 and 60 minutes. This phenomenon is probably due to a 


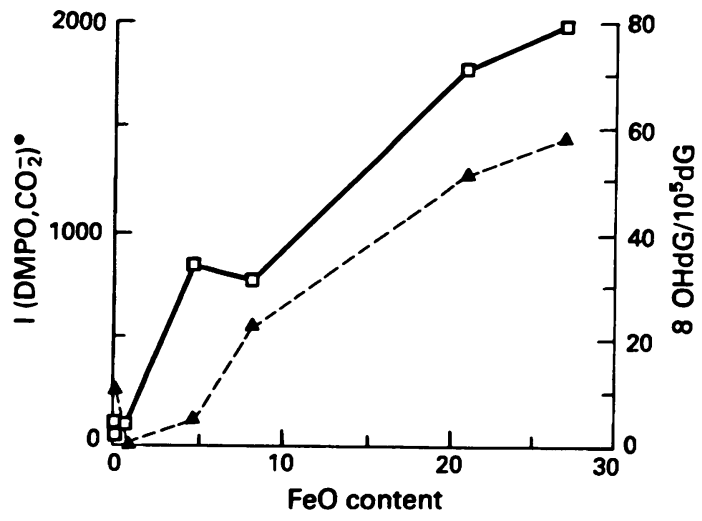

Figure 2 Evolution of the oxidative effect in the two tests in relation with the $\mathrm{FeO}$ content of the materials (values for wollastonite are not represented). $\square: d G$ oxidation; $\boldsymbol{\Delta}$ : formate oxidation.

release of $\mathrm{Fe}^{\mathrm{II}}$ in solution that destroys the radical adducts.

Despite the anomalies for wollastonite and anthophyllite, the results of the two tests allow us to consider that there are three categories of materials capable of generating different amounts of $A^{\star}$ species and consequently different degrees of oxidative stress in lung medium. Among the most active materials are amosite and crocidolite. By contrast erionite, glass wool, ceramic fibres, xonotlite and Tismo $\mathrm{L}$ were found to be inactive by both methods. There is however a group containing anthophyllite, iron rich rock wool, and wollastonite, that possibly generate a moderate quantity of $A^{\star}$ species, and hence, after considerable exposure, various biological effects due to an oxidative stress.

With reference to the classical relation between the appearance of electrophilic species among the metabolites of a xenobiotic and the process of carcinogenesis, ${ }^{12}$ it is possible to consider the materials able to generate a high quantity of $A^{\star}$ species as potential carcinogens. But, independent of these $A^{\star}$ species other less electrophilic species $P^{\star}$-not studied in the present paper-must be considered. ${ }^{2}$ Fournier et al have shown for example, that erionite and UICC crocidolite (not ground), both carcinogenic in mesothelial tissue, are not able to generate $\mathrm{A}^{\star}$ species, but are capable of producing $\mathrm{P}^{\star}$ species active in lipid peroxidation. ${ }^{13}$

This approach to genotoxicity by tests of oxidative properties generated by the materials in an aqueous medium allows us to screen and to select compounds able to trigger an oxidative stress by a given mechanism. To obtain a more precise appreciation of the probable carcinogenic properties, it is necessary to consider various biological conditions such as the capacity of the dust to be cleared, to be internalised into epithelial cells, to be dissolved in the biological medium, and finally to be rendered passive by an oxidative pathway.

We thank NYCO Cie, PROMAT $\mathrm{Cie}$, and OTSUKA Chemicals for providing us with commercial samples. Our thanks to Ligue contre le Cancer (Comité du Val d'Oise) for financial aid. We also thank Mr Morin for technical help with EPR spectroscopy and Mrs C Coupas for her secretarial assistance. Parts of this work were supported by the Swedish Work Environment Fund (900140).

1 Lund GL, Aust EA. Iron catalyzed reactions may be responsible for the biochemical and biological effects of asbestos. Biofactors 1991;3:83-9.

2 Pezerat $\mathrm{H}$. The surface activity of mineral dust and the process of oxidative stress. In: Brown RC, Hoskins JA, Johnson NF, eds. Mechanisms in fibre carcinogenesis. Berlin: Springer-Verlag, 1991:387-95. (NATO ASI Series.)

3 Zalma R, Bonneau L, Jaurand MC, Guignard J, Pezerat H. Formation of oxy-radicals by oxygen reduction arising from the surface activity of asbestos. Canadian fournal of Chemistry 1987;65:2338-41.

4 Costa D, Guignard G, Zalma R, Pezerat H. Production of free radicals arising from the surface activity of minerals and oxygen. Part I. Iron mine ores. Toxicol Ind Health 1989; 5:1061-78.

5 Nejjari A. Etude des propriétés électrophiles générées en milieu aqueux par les composés du fer et les métaux. Relations avec une approche mécanistique des propriétés cancérogènes de ces matèriaux. Paris: Université Paris 6, 1992 (Thesis.)

6 Costa D, Guignard J, Pezerat H. Production of free radicals arising from the surface activity of minerals and oxygen. Part II. Arsenides, sulfides, and sulfo arsenides of iron, nickel, and copper. Toxicol Ind Health 1989;5:1079-97.

7 Costa D, Guignard J, Pezerat $\mathrm{H}$. Production of free radicals by non-fibrous materials in a cell free buffer medium. In: Mossman BT, Bégin RO, eds. Effects of mineral dusts on cells. Berlin: Springer-Verlag, 1989:189-96. (NATO ASI Series H30.)

8 Leanderson $P$, Söderkvist $P$, Tagesson $C$. Hydroxyl radical mediated DNA base modification by manmade mineral fibres. $\mathrm{Br} \mathcal{F}$ Ind Med 1989;46:435-8.

9 Leanderson P, Söderkvist P, Tagesson C, Axelson O Formation of the DNA adduct 8-hydroxydeoxyguanosine induced by manmade mineral fibres. In: Bartsch $\mathrm{H}$, Hemminki K, O'Neill IK, eds. Methods for detecting DNA damaging agents in humans, applications in cancer epidemiology and prevention. Lyon: International Agency for Research on Cancer, 1988:422-4. (Sci publ No 89.)

10 Cadet J, Berger M, Decarroz C, Mouret JF, Van Lier JE, Wagner RJ. Photo- and radiation-induced radical oxidation of the purine and pyrimidine bases of nucleic acids. Fournal de Chimie Physique 1991;88:1021-42.

11 Kasai $\mathrm{H}$, Nishimura $\mathrm{S}$. Hydroxylation of deoxyguanosine at the $\mathrm{C}-8$ position by ascorbic acid and other reducing agents. Nucleic Acid Res 1984;12:2137-45.

12 Pitot HC. Mechanisms of chemical carcinogenesis: theoretical and experimental bases. In: Cooper CS, Grover PL, eds. Chemical carcinogenesis and mutagenesis. Berlin: SpringerVerlag, 1990;I:3-29.

13 Fournier J, Guignard J, Nejjari A, Zalma R, Pezerat H. The role of iron in the redox surface activity of fibres. Relation to carcinogenicity. In: Brown RC, Hoskins JA, Johnson NF, eds. Mechanisms in fibre carcinogenesis. Berlin: SpringerVerlag, 1991:407-14. (NATO ASI Series.)

Accepted 3 August 1992 